\title{
Quality of Urban Space in The Eurasian Context The Case of Almaty (Kazakhstan)
}

\author{
Farida Alzhanova ${ }^{1}$ David Celetti2, $^{2 *}$ Nailya Nurlatova ${ }^{1}$ Zaira Satpayeva $^{1}$ \\ ${ }^{1}$ Institute of Economy of Committee of Science of the Ministry of Education and Science of the Republic of \\ Kazakhstan, Kazakhstan \\ ${ }^{2}$ Department of Historical, Geographical Science and of the Antiquity, University of Padua, Italy. \\ *Corresponding author. Email: david.celetti@unipd.it
}

\begin{abstract}
The article's aim is to assess the factors determining the quality of urban spaces as districts, quarters, neighborhoods. Methodologically the paper juxtaposes the analysis of selected scientific literature, with that of the transformations of the city of Almaty (Kazakhstan) from the mid 20th century. The case study has been selected for its significance within the Eurasian context, the relevance of the transformations that, in the last century, molded the city's present, and its inner differentiation, single districts having showed quite different development path, deeply contributing in determining actual quality of life of their inhabitants. After having discussed selected scientific literature on the topic, the paper analyses the different districts of the city, verifying, through empirical reconstruction of their origins and transformations, how, in the course of history, they assumed diverse, and sometimes diverging characters directly influencing the quality of their urban space. Quality of life in single districts has been assessed using a set of quantitative indicators as safety, comfort of living, environment, diversification and modernity of structures and services, business environment, social development, and human capital. Indicators, therefore, reflect features used as proxies for evaluating the city's standards. Indicators have been constructed exploiting open sources data produced by the Department of Statistics of Almaty, the Committee on Legal Statistics and Special Records of the General Prosecutor's Office of the Republic of Kazakhstan, the Department of Emergency Situations of Almaty, 2GIS, RSE Kazhydromet. The results of the research demonstrate that the city of Almaty is still characterized by high inner differences in terms of level of development; that these diversities have historical roots; and that development projects, far from reducing them, have in fact contributed to enhance distances between "high quality" and "poor quality" areas. This last point is of the utmost importance. As conclusion, in fact, the paper suggests that future urban policies should try to reduce difference before implementing further development plans especially in terms of special expansion, in order to avoid the risk of ever greater unbalances
\end{abstract}

Keywords: Almaty, Eurasia, Urban Space, Urban History, Urban Economy, Economic History, Urban development.

\section{INTRODUCTION}

Today, more than half of the 7.5 billion people on Earth live in cities. By 2050, the proportion of urban residents will presumably reach to $66.4 \%$ of the world's population [1]. This plain data shows that cities play a crucial role in the development of countries and regions, being engines, or "poles", of national, and global economic growth.

Urban spaces are, however, very complex entities, emerging from dialectical relations between physical (urban structures), economic (urban production and consumption of goods and services), social (human capital), and cultural (inhabitants' self-consciousness, and behavior) factors. Besides in their evolution cities often face problems of unbalanced development within their own boundaries. This determines uneven use of the territory, diverse levels of transport accessibility, of service facilities, of production and distribution facilities [2]. Moreover, uneven spatial development implies social and economic polarization. The process is all the more complex that 
urban spatial structures are resistant to changes, and encompass successive architectural layers, which makes comprehensive interventions difficult [3].

The paper analyses the quality of urban spaces of the city of Almaty with a focus on the problems of intra-city different path of development. It juxtaposes a diachronic analysis of the transformation of different areas, with a study of single districts exploiting quantitative indicators. Almaty is a relevant case study. It entails a large economic, intellectual and creative potential. The city provides, $22.5 \%$ of Kazakhstan gross domestic product (GRP), $25 \%$ of the volume of services, more than $20 \%$ of tax revenues, $54 \%$ of financial, and insurance services, $47 \%$ of retail and wholesale trade, a sixth of foreign trade turnover, $7.5 \%$ of investments in fixed assets [4]. However, if urbanization processes have been analyzed from many points of view, less attention has been paid to the causes and effects of differences between areas within the cities themselves, which is namely the core topic of the present paper.

\section{THEORETICAL REVIEW}

Scholars identified different factors determining effective urban structures.

According to $\mathrm{M}$. Weber, urban structures are defined by the presence within a limited space of such elements as diverse social and economic activities; nets of exchange of goods and services; consolidated ways for regulating land relations, as well as for managing core functions as, e.g., insuring safety, and regulating economic activities [3]. M. Weber also divides cities into two groups: cities of consumers, and cities of producers. The first group depends for economic development on the presence among its population of consumers of diverse economic conditions (e.g. officials, "rentiers", etc.). Cities of manufacturers, on the other hand, host the enterprises selling their goods outside the city [3].

In the 1930s, W. Kristaller formulated the "law of spatial distribution". Space is interpreted as a hierarchy of settlements around a "central place", the city, providing surrounding settlements with goods, and services [4]. This hierarchy determines the territorial organization, and the distribution of vital functions as education, health, trade, finance, etc. which are offered within the framework of "the radius of the sale of services and goods". According to this theory, central places, the cities, will tend to form a "service area" around them that is compact in shape and can be represented as a regular hexagonal grid [4].
A. Losch developed further the works of W. Kristaller formulating the theory of economic landscapes. This approach analyses the interweaving of market zones of different goods and services to demonstrate that spatial economic equilibrium corresponds to the conditions when the location of each firm provides the greatest possible benefits to both consumers, and producers. Businesses are therefore located in such a way that optimally exploited the territory, balancing prices and costs [5].

J. Friedman developed the concept of "centerperiphery". According to this approach space polarizes between center and periphery at global, regional, and local level. At all levels it can be found a compact center, which enjoys of the most advanced technological, and social conditions, surrounded by areas of less developed peripheries. Periphery however might get into processes of delayed modernization through the "diffusion of innovations", i.e. the transfer of part of the center's innovations to adjacent territories [6].

E. Burges's concentric zones model interpreted spatial structures of traditional cities within a radialcircular matrix [7]. The model identifies diverse zones as core, business and cultural center, transitional zone of residential development and trade enterprises, high income living area, comfortable living area, and commuters' zone.

J. Jacobs focused on the diversity of the use of space, highlighting that the most important conditions for a full-fledged city life are rooted namely in the different, tough complementary, uses of streets, open spaces, and other public areas that gives to residents a sense of mutual economic, and social support [8].

In 1970 J. Danzig and T. Saati elaborated the concept of "compact city" providing by this way a first framework for interpreting "spreading" cities [9]. The model is based on two principles, explaining the use of space and time. The construction of cities with high density of vertical buildings, mixed environmental functions, and modern public transport was for that time still a futuristic project highlighting the potentials of innovation, and of information technology, but also stressing the relevance of strong cores as place where key functions of the city should be concentrated.

Finally, in the 1980s emerged the concept of new urbanism that tries to answer to the ever more relevant need of improving the quality of urban environment [10]. Combining basic, historically grounded humanistic principles of urbanism, and reinterpreting the traditional organization of space within a 
convenient road grid and compact "pedestrian" zones, new urbanism focuses on buildings integrity, and on their proportion in relation to human scales, on public spaces where people can relax, express themselves, but also develop their business and economic activities. Connectivity, and pedestrian accessibility, infrastructure for alternative transport, multifunctionality, and mixed use of territories are valued features helping to create favorable places for free time and work alike [11].

Within the above mentioned theoretical framework, many scholars specifically focused on the Kazakh case, highlighting in particular patterns of urban evolution in post-soviet time with reference to major cities as Astana and Almaty [12, 13, 14, 15, 16, 17], or focusing on specific aspects as, for example, access to housing [17] and health care [18], personal security and crime [19], daily life, social relations and conditions [20, 21, 22, 23], social configuration [24], economy [25, 26, 27] and environment [28, 29, 30], communications and infrastructures. Though encompassing crucial topics, still a few works [31] tackled the problems of urban asymmetries as a limit for sustainable, long term city's development.

\section{RESEARCH METHODOLOGY}

Building on the theoretical categories of the above mentioned studies, the paper assesses the quality of the urban space of the city of Almaty in its diverse territorial expressions. Given the different approaches for assessing the characteristics of an urban environment, we have chosen to focus first of all on the analysis of administrative districts, as they build broadly homogeneous areas, and present a historically grounded evolution [32, 33, 34]. For overcoming possible differences in available data, we have opted for addressing to a wide range of different sources, as the Department of Statistics of Almaty, the Committee on Legal Statistics, and Special Accounts of the General Prosecutor's Office of the Republic of Kazakhstan, the Department of Emergency Situations of Almaty, 2GIS, RSE Kazhydromet, the hydrometeorological company operating in Almaty. This approach allowed us to acquire a large set of data, and to calculate different indicators reflecting the basic characteristics of a modern city, as safety, comfort, ecological environment, diversity and modernity of structures and services, business environment, quality of life, social development, and human capital.

We have also taken into account the different stages, functions, and development characteristics that contributed in forming the city's urban space, identifying four territories, each reflecting the specific characteristics of their formation over more than 50 years. The territorial approach also aims to encompass in our analysis the effects of 2014 enlargement of the city's boundaries that enhanced the complexity of urban development management, affected the structure of urban space itself, and made it more heterogeneous, multifaceted, and unbalanced.

\section{RESULTS}

Almaty's territory can be analyzed on the basis of its functional formation, or of its administrative divisions [figure 1], both approaches highlighting slightly different aspects. Functionally Almaty can be divided into four areas, each emerging from the particular dynamics of urban construction that affected the city over at least 50 years. We can therefore identify an historic center with adjacent business areas; housing district used essentially as sleeping, residential areas; spaces of low, mostly one stage buildings; and new annexed areas characterized by unregulated individual housing construction.

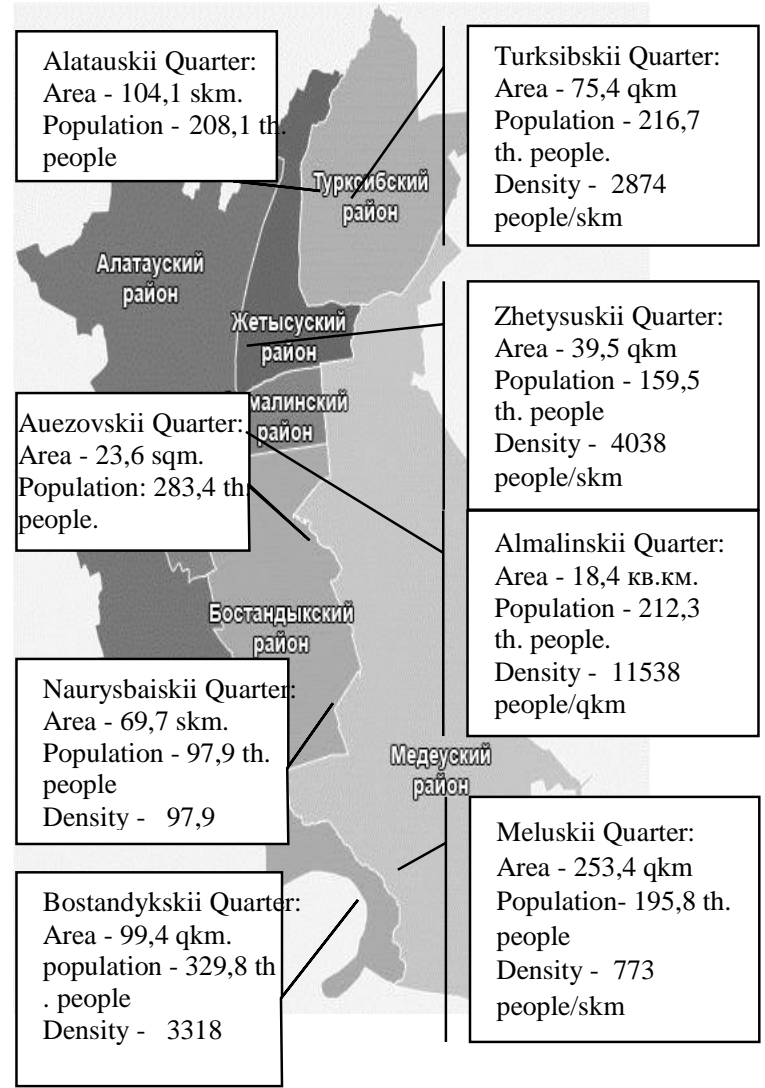

Figure 1 Population and Surface of the Almaty Quarters (16).

configures a highly regular, and rational city center. The rectangular layout of quarters, the wide and 
geometrically designed streets is meant to provide good transport, and pedestrian accessibility, as well as comfortable housing conditions. This approach is grounded on a clear scheme of space organization, and orientation providing not only a "sense of geographical certainty", but also a "sense of emotional balance and well-being". In the late 1980s, the original urban core was enlarged to encompass new the business centers in the southern part of the city.

The second area was actively developed from 1950 s to the 1990s as a space of integrated housing facilities aimed to host the growing city population. The area recently has been rediscovered, and it now experiences a renewed life thanks to projects of integrated social housing. Despite the limits of Soviet time urban planning approaches, it is to be stressed that they generally succeeded in creating basic infrastructures to respond to the growing social needs. This aspect became ever more evident by contrast after the collapse of the Soviet Union. In the 1990s as the first wave of privatization began in Kazakhstan, many social facilities were sold to be reconverted into private business facilities, leaving a wide demand for social services broadly unaddressed. This part of the city is still in transformation. It is noteworthy, in fact, that in Almaty every year there are issued about 1,200 authorizations for renovation of the first floors of multi-stores buildings, many of them concentrated in this area. This is an evidence of the involvement of the private sector in the transformation of a territory otherwise characterized by dense, multi-stores residential constructions into new multifunctional areas. Such a gradual approach does not lead to fundamental changes, but it allows nevertheless transforming local spaces re-designing them in relation to the new needs of the local communities.

The third part entails the vast area of low-rise residential buildings, and industrial zones in the Turksib and Zhetysk districts, as well as rather large parts of the territories of the three central districts of Almaly, Medeu, and Bostandyk. This is quite a complex territory, where low-rise, often one-floor buildings are set within a

complicated road grid, with intermittent streets, dead ends, tortuous paths making it unsuitable for public and private transport.

The fourth part of the city is formed by new, and non-central areas, that have been "added" to the city's core in two phases, respectively in 2008, and 2014. In these parts clearly emerge the consequences of the market reforms in the 1990s on the social structure of the city. As the role of the state in housing issues weakened, many services remained unfulfilled, which determined new problems in urban planning. Large immigration flows in absence of housing programs, in particular, accentuated social polarization in different parts of the city.

If we look at the urban structure through the framework of its administrative divisions, we see a slightly different, but by no means less heterogeneous, picture.

The Almalinsky and Auezovsky districts present the smallest area, and the highest population density, aspects that resulted from the processes that in the time generated the city's territorial structure. First of all the areas are "internal", i.e. without access to the external border of the city. This by itself implies trends of inner concentration of social and economic activities. The Almalinsky district, then, is historically the economic and cultural heart of the metropolis, and still performs the functions of a "core space" with a very high concentration of business activity. Besides it hosts major medical centers, cultural facilities, parks, theaters, universities. It also occupies an interesting geographical position. It is bordered by the five other city districts an aspect contributing in explaining its role of central point within of an imaginary "crystal lattice". Auezov district, on the other hand, though predominantly a "sleeping area", hosts 18 major factories, which produce almost $12 \%$ of the city's industrial production.

Medeu is the largest district, covering almost 30\% of the city's surface. By population density is still peripheral. However, it hosts the historical center of Almaty. The modern boundaries of the district include low-rise residential development zones in its southern and eastern parts, natural parks and extensive green spaces forming a basis for tourism and recreation.

The Bostandyk District is the third largest district and performs functions of a central area dominated by a large concentration of business infrastructures, and educational institutions. Its historical development patterns, as well as the dominance of low-rise buildings, above all in its southern part, explain its limited population density.

Zhetysu, Turksib, Alatau and Nauryzbay districts are typically marginal territories. The last two, in particular, have been created only recently and still have great difficulties in creating the pre-conditions for attracting entrepreneurial activity, and investment.

Along with the above-mentioned differences, the uneven development of the city's districts is clearly reflected by a number of diverse indicators reflecting safety, comfort of life conditions, environment, 
diversity of housing conditions, access to leisure services, and to modern services and infrastructures, business environment, quality of life, social development, and human capital [Table 1].

Table 1. Quality of Almaty Urban Space (2017)

\begin{tabular}{|c|c|c|c|c|c|c|c|c|}
\hline Indicator & Alatau & $\begin{array}{l}\text { Almali } \\
\text { nsky }\end{array}$ & $\begin{array}{l}\text { Auezo } \\
\text { vskiy }\end{array}$ & \begin{tabular}{|l|} 
Bostand \\
yk
\end{tabular} & Zhetysu & Medeu & $\begin{array}{l}\text { Nauryzb } \\
\text { ai }\end{array}$ & Turksibsky \\
\hline \multicolumn{9}{|c|}{ Security } \\
\hline $\begin{array}{l}\text { Share of damaged and unsafe } \\
\text { houses, \% }\end{array}$ & 0,8 & 9,5 & 0,9 & 5,4 & 3,2 & 2,4 & 0,0 & 9,8 \\
\hline Quantity of fires, unit $/ \mathrm{km}^{2}$ & 1,1 & 3,6 & 2,8 & 0,9 & 2,3 & 0,5 & 0,7 & 1,3 \\
\hline Quantity of fires, unit & 116 & 66 & 65 & 89 & 92 & 122 & 49 & 97,0 \\
\hline $\begin{array}{l}\text { Quantity of crimes, quantity of } \\
\text { crimes on } 10 \text { thousand } \\
\text { inhabitants }\end{array}$ & 358 & 798,6 & 483,7 & 353,9 & 502,2 & 484,4 & 232,9 & 286,0 \\
\hline $\begin{array}{l}\text { Crimes against minors in } \\
2016, \text { number of crimes on } \\
10,000 \text { inhabitants }\end{array}$ & 131,9 & 277,7 & 176,6 & 157,1 & 197,9 & 266,9 & 191,7 & 185,8 \\
\hline \multicolumn{9}{|c|}{ Comfort } \\
\hline $\begin{array}{l}\text { Total area equipped with } \\
\text { central hot water, \% }\end{array}$ & 21,8 & 93,5 & 83,0 & 84,9 & 67,9 & 66,7 & 20,9 & 58,4 \\
\hline $\begin{array}{l}\text { Green Area, \% of inhabitants } \\
\text { living in areas nearby green } \\
\text { areas }\end{array}$ & 3,1 & 29,8 & 2,3 & 43,7 & 18,3 & 60,3 & 4,5 & 89,6 \\
\hline \multicolumn{9}{|c|}{ Ecology } \\
\hline $\begin{array}{l}\text { Quantity of Municipal solid } \\
\text { Waste per Inhabitant, } \\
\text { ton/person. }\end{array}$ & 54,3 & 332,5 & 318,4 & 241,4 & 434,5 & 339,9 & 0,0 & 336,7 \\
\hline $\begin{array}{l}\text { Quantity of removed } \\
\text { Municipal solid Waste, tonn }\end{array}$ & 11302,0 & 70580,0 & 90228,0 & 79617,0 & 69301,0 & 66546,0 & & 72958,0 \\
\hline $\begin{array}{l}\text { Pollutants emitted in the } \\
\text { atmosphere in the reporting } \\
\text { year, tons }\end{array}$ & 32070,2 & 398,2 & 907,6 & 721,8 & 2134,4 & 567,0 & 140,7 & 1839,2 \\
\hline \multicolumn{9}{|c|}{ Uniformity and Diversity } \\
\hline
\end{tabular}




\begin{tabular}{|l|c|c|c|c|c|c|c|c|}
\hline $\begin{array}{l}\text { Differences in residential } \\
\text { constructions (> 75- low level } \\
\text { of diversity) }\end{array}$ & 66,5 & 68,8 & 67,7 & 65,7 & 79,0 & 77,2 & 63,5 & 80,5 \\
\hline $\begin{array}{l}\text { Diversity in leisure facilities } \\
\text { quality (>75- low level of } \\
\text { diversity) }\end{array}$ & 74,5 & 68,8 & 61,5 & 70,2 & 81,2 & 52,6 & 100,0 & 71,1 \\
\hline
\end{tabular}

Quality of Life

\begin{tabular}{|l|c|c|c|c|c|c|c|c|}
\hline $\begin{array}{l}\text { Differential ration between the } \\
\text { average market price of 1QM } \\
\text { with the price of the most } \\
\text { expensive quarter, \% }\end{array}$ & 54,2 & 71,2 & 61,0 & 77,5 & 53,0 & 100,0 & 69,5 & 50,8 \\
\hline $\begin{array}{l}\text { Average price for QM (Tenge) } \\
\text { 258400,0 }\end{array}$ & 339100 & 290700 & 369200 & 252700,0 & 476500,0 & 331300 & 242100,0 \\
\hline
\end{tabular}

Modernity

\begin{tabular}{|l|c|c|c|c|c|c|c|c|}
\hline $\begin{array}{l}\text { Number of banks offering } \\
\text { ATMs }\end{array}$ & 10,0 & 20,0 & 16,0 & 19,0 & 15,0 & 19,0 & 8,0 & 15,0 \\
\hline $\begin{array}{l}\text { Number of payment structures } \\
\text { Number of shopping centers, } \\
\text { and supermarkets }\end{array}$ & 7 & 18 & 22 & 18 & 12 & 12 & 0 & 6 \\
\hline Shopping centers, ед. & 2 & 3 & 6 & 7 & 1 & 3 & 0 & 1 \\
\hline
\end{tabular}

Business

\begin{tabular}{|l|c|c|c|c|c|c|c|c|}
\hline Quantity of firms & 3196 & 2816 & 1520 & 2539 & 1067 & 2019 & 1045 & 6764 \\
\hline Ratio active firms, \% & 37 & 30 & 29 & 27 & 30 & 27 & 28 & 33 \\
\hline
\end{tabular}

Social Sphere and Human Capital

\begin{tabular}{|l|c|c|c|c|c|c|c|c|}
\hline $\begin{array}{l}\text { Average monthly nominal } \\
\text { wage, Tenge }\end{array}$ & 178678 & 132533 & 173013 & 127338 & 201042 & 129155 & 235564 & 120653 \\
\hline Ration Unemployment & 5,4 & 5,4 & 5,4 & 5,4 & 5,4 & 5,4 & 5,4 & 5,4 \\
\hline $\begin{array}{l}\text { Migration Balance (number of } \\
\text { people) }\end{array}$ & 12263 & 1281 & -958 & -468 & -559 & 3297 & 8379 & 4397 \\
\hline $\begin{array}{l}\text { Natural population growth per } \\
\text { 1000 people }\end{array}$ & 21,1 & 9,7 & 14,1 & 7,1 & 14,1 & 9,8 & 13 & 10,8 \\
\hline
\end{tabular}

Source: (www.stat.gov.kz (Accessed 20 November 2017); kazhydromet.kz (Accessed 20 November 2017); https://informburo.kz/stati/vspiskah-akimata-ne-chislyatsya-29-almatinskih-parkov-issledovanie.html (Accessed 1 December 2017)); 2) Index Herfindahl-Hirschman 
Security has been assessed through the share of housing in dangerous conditions, the number of fires, and the crime rate. A significant proportion of old, and sometimes almost crumbling housing is located in the central districts of Almaty, which indicates that not only the suburbs, but also the historical center needs to be renovated, and modernized. This information is relevant as it gives clear indications in terms of investment plans for renovating residential areas. High crime rate, and frequency of fires, on the other hand, are signals of increased risk and highlight the areas that need city services to ensure public safety, which, in turn, is a prerequisite for long term development.

Comfortable environment for daily life as well as for business can be assessed through different proxies, as accessibility and convenience of transport, provision of basic utilities (water, heat, gas, electricity, internet), and presence of green spaces. In our case, we used two indicators that are available in all areas of Almaty - the share of the total area equipped with central hot water supply, and the share of green areas. Other indicators, as for example, accessibility to transport or shopping facilities, having not yet a sufficiently precise statistical basis.

The limited availability of central water supply or of energy facilities is a strong signal for business, as it may imply additional costs in comparison to better equipped areas. The level of infrastructural facilities in non-central areas strongly contrasts with that of the central ones, as highlighted, for example, by the low pro portion of buildings equipped with central hot water in the Nauryzbay and Alatau districts, confirming the relative backwardness of the "peripheries" in comparison to the central quarters.

The presence of large green areas also convoys relevant information. First of all, territories well provided with green space provide comfortable life, and are comparatively "cleaner". Therefore, they are more attractive both for private and business. On the other hand, large green areas are often unsafe, unless provided with suitable surveillance services. Low security makes the areas unattractive, especially for emerging creative business addressing to high-level clients.

Environmental quality has been considered on the basis of the amount of Municipal Solid Waste (MSW) removed per capita, and of the emissions of pollutants into the atmosphere. High level of air pollution strongly influences the prices of real estate, affects business and private investments, and limits the creation of socially significant infrastructures (for example kindergartens, cafes, medical centers, etc.).

Modernity and diversity in housing and services are also important indicators. The diversity of leisure facilities as a whole, influences to a certain extent the degree of poly-centricity of a city's development, determining a hierarchy of services in central, and noncentral areas. For example, a variety of leisure facilities attracts more consumers, which has a positive effect on business opportunities, in investment, and in the area development.

Finally, from our researches it emerges that market price (average square meter value calculate on single districts might be assumed as proxy of social composition, as more expensive areas are also those presenting higher standards of living and quality of life, as described by our parameters. Consequently, we can assume that better services, infrastructures, cleaner environment, or higher security levels contribute in attracting, and in the long run concentrating, affluent inhabitants, which, in turn, further boosts the demand for those same conditions determining quality of life itself.

Indicators of average wages, unemployment and fertility reflects the evolution of the social situation in specific urban spaces, mirroring ongoing conditions, and prefiguring possible development in absence of external interventions. The high fertility, and immigration flows of some areas prefigure future increase in investment in social infrastructure, housing, etc.

\section{CONCLUSION}

Over the past decade and a half, Almaty changed significantly. Its boundaries have expanded, transport infrastructures modernized. However, as we have seen, the dynamics, and results of these processes have been uneven, leaving certain parts of city well beyond the others, creating territorial distortions, and alimenting tensions. All the indicators, from that broadly addressing quality of life to those depicting environmental conditions or business activity confirm such interpretation.

In our opinion, the polycentric approach, though potentially viable, entails the risk of fragmentation of a single urban space and a single labor market into a set of self-contained, and closed territories, especially if applied to an already uneven context as the one we have just examined. The above mentioned, approach would be by far more effective if juxtaposed to set of measures insuring the development of the spatially marginal, and off-centered areas, as well as of consolidation and integration of diverse urban spaces. In that way it would be possible di balance uneven spatial structures, and exploit at the same time territorial differences.

Besides, transforming Almaty in a global city local necessarily implies making it an active player, including, from an economic point of view, as an exporter of goods, and services to foreign markets. It is therefore important to develop modern sectors, as high technology. The key prerequisite for this, in turn, is to invest in infrastructures making the city attractive for such businesses including in its non-central areas. 
In addition to large-scale work on infrastructure in non-central areas, which are actually being carried out by the Akimat (regional government) - for example repairing roads and communications, ensuring public safety, and access to public services - efforts should be directed in creating a broadly comfortable environment. In this context priority should be given to the development of cultural, and leisure facilities, of educational, and research institution. Such an approach would certainly improve life condition. But it would indirectly also contribute in opening new opportunities for business, and therefore enhance employment, especially in highly innovative sectors. As shown by other experiences, development management within the framework "live, work and play" strongly influences the way in which peripheries reach better living conditions.

The prerequisite for such a program is the presence of institutions ready to large-scale investments in newly attached areas especially focused on the creation of business parks surrounded by a wide range of social infrastructures, a sort of "enterprise ecosystem" attracting by itself smart businesses.

\section{ACKNOWLEDGMENTS}

This paper was prepared within the framework of the study "The Private Business Impact on Almaty's NonCentral Districts Development", funded by Chevron Kazakhstan and Urban Forum Almaty. The research team is grateful for the assistance in conducting the study granted by experts - business representatives and experts who participated in the in-depth interviews.

\section{AUTHORS' CONTRIBUTION}

Though the paper has been prepared by team work by the authors', prof. Celetti focused more no theoretical analysis, whereas the other member of the team worked especially on empirical research.

\section{REFERENCES}

[1] 1. United Nations, Department of Economic and Social Affairs, Population Division, World Urbanization Prospects: The 2014 Revision, 2015.

[2] 2. A. Bertaud, The spatial organization of cities: Deliberate outcome or unforeseen consequence? in: working paper 2004-01, Institute of Urban and Regional Development University of California at Berkeley, 2017.

[3] M. Weber, The City, Gorod Izbrannye proizvedenija, Progress, Moskva - 1990.

[4] W. Christaller, C.W. Baskin, The Central Places of Southern Germany, Englewood Cliffs, N. I: Prentice-Hill, 1966.
[5] A. Loesch, The economies of location, Prostranstvennaja organizacija chozjajstva, Nauka, Moskva, 2007.

[6] J. Friedmann, Regional Development Policy: A Case Study of Venezuela, MIT Press, Cambridge, 1966.

[7] E.W. Burgess, The Growth of the City: an Introduction to a Research Project, in Park R.E. et al. (eds.), The City, University Chicago Press, Chicago, 1925, pp.47-62.

[8] J. Jacobs, The death and Life of Great American Cities, Novoe Izdatelstvo, Mosckva, 2011.

[9] G. Danzig, T. Saati, Compact city: a Plan for a Livable Urban Environment, 1977.

[10] A. Duany, New Urbanism: The Case for Looking Beyound Style, Novyi urbanizm: Vsio luchshe v zentre: eto nepravilno, Stroitel'stvo Technologii Organizaziya, 133 (In Rus.).

[11] B. Lee, P. Gordon, Urban structure: its role in urban growth, net new business formation and industrial churn, Region et Development 3 (2011) 137-159.

[12] G. Alibekova, A. Panzabekova, Z. Satpayeva, N. Abilikayir, Sustainable Development Issues of Almaty as the largest Metropolis in Central Asia, Earth and Environmental Science 177 (2018) 1-6. DOI: $10.1088 / 1755-1315 / 177 / 1 / 012010$.

[13] B. Köppen, The Production of a new Eurasian capital on the Kazakh steppe: Architecture, Urban Design and Identity in Astana, Nationalities Papers, 41(4) (2013) 590-605.

[14] M. Janussova, Cities and Local Government in Central Asia: Administrative, Fiscal and Political Urban Battles, London \& New York, Routledge Advances in Central Asian Studies, 2020, 138.

[15] A. Panzabekova, G. Nurlikhina, G. Uakhitova, The Impact of the Transfer of the Capital to the Development of Almaty City, in: XIV International Conference "Russian Regions in the Focus of Changes", Ekaterinburg, RF, 14-16.11.2020, 96105.

[16] G.A. Mulagulov, Modern Landscaper Organization of the Almaty City, Nauka I Obrazovanie sevodnya, 1(48) (2020) 76-79.(In Russ.)

[17] W. Seitz, Urbanization in Kazakhstan: Desirable Cities, Unaffordable Housing and the Missing Rental Market, International Journal of Urban Sciences, 2020, (article in press), DOI: 10.1080/12265934.2019.1709534.

[18] B.S. Turdaliyeva et alii, Assessment of Health Care Quality by Population of Almaty: a Cross-sectorial 
Study, Human Ecology 11 (2017) 56-64. DOI: 10.33396/1728-0869-2017-11-56-64.

[19] A. Karipova, O. Voznyak, Y. Babajanyan, A. Serkbayev, Z. Kozhantayeva, About the Influence of Population Growth, Unemployment on the Crime Situation in the Cities of Astana and Almaty, International Journal of Environmental and Science Education 11 (11) 2016 4790-4800.

[20] G. Panicciari, The construction of an urban community in the Suburbs of Almaty (Kazakhstan): Citizenship and State through the daily Life in the District of Shanyrak, Quaderni Storici 50 (2) 355184. DOI: $10.1408 / 81786$.

[21] C. Alexander, Almaty: Rethinking the Public Sector, in V. Buchi, C. Humphrey, Urban Life in postSoviet Asia, UCL Press, 2007, pp.70-101.

[22] A.B. Shabdenova, G.T. Alimbekova, Religious Harmony and Tolerance of the Urban Residents in Kazakhstan, Results of the Sociological Research, RUDN Journal of Sociology 19(2) (2019) 302-312. DOI: 10.22363/2313-2272-2019-19-2-302-312.

[23] A. Bissenova, The Fortress and the Frontier: Mobility, Culture and Class in Almaty and Astana, Europe-Asia Studies 69(4) (2017) 642-667, DOI 10.1080/09668136.2017.1325445.

[24] M.V. Kasikci, The Soviet and the Post - Soviet: Street Names and National Discourse in Almaty, Europe-Asia Studies 71 (2019) 1345-1366. DOI: 10.1080/09668136.2019.1641586.

[25] S.D. Ussubaliyeva, A. Uaisova, G.D. Aitbayeva, M.K. Zhubanova, Y. Bessekey, Assessment of the Attractiveness of Sacred Tourism, International Journal of Criminology and Sociology 9(6) (2020) 1006-1011.

[26] H.H. Karrar, The Bazaar in Ruins: Rent and Fire in Barakholka, Almaty, Central Asian Survey 39 (1) (2020) 80-94, DOI: 10.1080/02634937.2020.1732299.

[27] H. Aiff, Profiteers or Moral Entrepreneurs? Bazaars, Traders, and Development Discourses in Almaty, Kazakhstan, International Development Planning Review 37 (3) (2015) 249-267, DOI: https://doi.org/10.3828/idpr.2014.28

[28] A. Medeu, V. Blagovechshenkij, V. Zhdanov, S. Ranova, Assessment and Mapping of Landslide Risk in the Territory of Amaty City, New of the National Academy of Sciences of the Republic of Kazakhstan. Series of Geology and Technical Sciences 1(427) (2018) 34-40.
[29] A. Pakina, A. Batkalova, The Green Space as a Driver of Sustainability in Post-Socialist Urban Areas: the Case of Almaty City (Kazakhstan), Belgium Journal of Geography 4 (2018) 1-17. DOI: https://doi.org/10.4000/belgeo.28865.

[30] A. Maulken, M. Alikhan, M. Akhmetkal, Assessing the Level of Environmental Health Security Affected by Atmosphere Pollution, European Journal of Geography 7 (2) (2016) 72-84.

[31] S. O. Mukhametzhan, G.A. Janusbekova, M.Ye. Daueshov, An Econometric Model for Assessing the Asymmetry of Urban Development as a Factor of Regional Economic Growth: the Case of Kazakhstan, Industrial Engineering \& Management Systems 19 (2) (2020) 460-475. DOI: 10.7232/iems.2020.19.2.460.

[32] S. Naghshpour. Determinants of economic growth rates of the newly formed countries of the former Soviet Union and Eastern Bloc. "International Journal of Economic Policy in Emerging Economies" 12 (5) (2019) 425-442.

[33] S. Revinova, E-Commerce in BRICS: Similarities and Differences. 'International Journal of Economic Policy in Emerging Economies" 12 (4) (2019) 377390.

[34] B. S. Sergi, A. Berezin, N. Gorodnova, I. Andronova, I., Smart Cities and Economic Growth in Russia. In Modeling Economic Growth in Contemporary Russia, Sergi, B.S. (Ed.), Emerald Publishing Limited, 2019, pp. 249-272. DOI: https://doi.org/10.1108/978-1-78973-265$\underline{820191010}$ 